Fournal of Medical Genetics (1976). 13, 229-234.

\title{
Trisomy 8 restricted to cultured fibroblasts*
}

\author{
RAINER NISS $†$ and EBERHARD PASSARGE \\ From the Institute für Humangenetik, Universität Hamburg, Hamburg, Germany
}

\begin{abstract}
Summary. In the course of re-examining cultured fibroblasts stored in liquid nitrogen from a patient with developmental retardation, solitary left kidney, and Wilms tumour, a cell line trisomic for chromosome 8 was found. Trisomy 8 was restricted to fibroblasts in the first 22 subcultures and was absent in later passages as well as in lymphocytes. A familial pericentric inversion of chromosome 2 was observed in three generations including the propositus but was thought to be unrelated to the clinical problem. Multiple spontaneous chromosomal rearrangements were seen in several late subcultures.
\end{abstract}

This study reports the association of a Wilms tumour in the solitary kidney of a patient with trisomy 8. In addition, it describes unusual diagnostic difficulties encountered in correlating karyotype and phenotype owing to the restriction of the trisomic cell line to cultured fibroblasts in their first 22 subcultures, and the presence of an apparently unrelated familial pericentric inversion of chromosome 2, along with multiple chromosomal structural rearrangements presumably arisen in vitro.

\section{Methods}

This family came to light in 1969 when the propositus was referred at the age of 6 years for evaluation of developmental retardation of undetermined origin. A familial pericentric inversion of chromosome 2 had previously been diagnosed elsewhere (Dr. R. A. Pfeiffer, Münster), which was confirmed. The patient was subsequently seen on a few occasions before his death in 1973 at the age of 10 years.

Metaphase chromosome preparations from cultured lymphocytes were obtained in 1969 and 1972. Fibroblast cultures were established from a skin biopsy taken in 1972 and frozen in liquid nitrogen after their fourth subculture, as described elsewhere (Böhmer et al, 1973).

Fibroblast-like cells were grown in Dulbecco's modified Eagle's medium (Grand Island Biological Co., New York), supplemented with $16.6 \%$ fetal calf serum (Gibco), $20 \mathrm{mmol}$ HEPES as buffer, penicillin (100 units $/ \mathrm{ml})$, streptomycin $(100 \mu \mathrm{g} / \mathrm{ml})$, and neomycin

Received 6 July 1975.

* Supported by grants from the Deutsche Forschungsgemeinschaft. t Part of a thesis by R.N.
$(100 \mu \mathrm{g} / \mathrm{ml})$. The cultures have not been tested for mycoplasma.

After mitotic arrest with Colcemid $(0.1-0.3 \mu \mathrm{g} / \mathrm{ml})$ for 2 hours and exposure to hypo-osmotic conditions ( $\mathrm{KCl}$ $0.075 \mathrm{~mol} / 1$ for 5 to 10 minutes in lymphocytes and $\mathrm{NaCl}$ $0.3 \%$ for 10 minutes in fibroblasts), chromosomal Giemsa (G) bands were produced according to Seabright (1972) with the following modifications: $0.16 \%$ trypsin for 10 to $20 \mathrm{~s}(0.23 \%$ trypsin for 50 to $70 \mathrm{~s}$ in fibroblasts), rinse in ethanol $70 \%$ and $96 \%$, Giemsa stain at $p \mathrm{H} 6.8$ in Sørensen-buffer. In addition, preparations with standard Giemsa stain were available. Metaphases selected according to the quality of their banding pattern were studied directly by microscopy and from microphotographs.

\section{Results}

Clinical data. The propositus was born at 40 weeks gestation with a birthweight of $3500 \mathrm{~g}$ and length of $50 \mathrm{~cm}$ to a 23-year-old mother and 26year-old father.

His subsequent clinical course revealed severe failure of both mental and physical deveopment as summarized in Table $\mathrm{I}$. When first seen by us at the age of $6 \frac{1}{2}$ years his height was $104 \mathrm{~cm}(-12 \mathrm{~cm})$, weight $16 \mathrm{~kg}(-5)$, and head circumference $50.5 \mathrm{~cm}$. $\mathrm{He}$ had an antimongoloid slant of his eyelids, a high arched round palate especially in its anterior part. A $2 \times 2 \mathrm{~cm}$ occipital area showed nearly unpigmented hair. His mental development was clearly impaired and corresponded to that of a child of approximately 2 years of age. He was unable to speak. Sight and hearing appeared normal. Clinically and on $x$-ray his pelvis appeared narrow. 
TABLE I

SUMMARY OF CLINICAL DATA OF PROPOSITUS

\begin{tabular}{|c|c|c|}
\hline Age & Presenting Symptoms & Main Findings \\
\hline $\begin{array}{l}2 \mathrm{~m} \\
3 \mathrm{~m} \\
1 \mathrm{y} \\
1 \frac{\mathrm{B}}{\mathrm{i}} \mathrm{y}\end{array}$ & $\begin{array}{l}\text { Vomiting, failure to thrive, recurrent fever } \\
\text { Vomiting, failure to thrive, recurrent fever } \\
\text { Retarded development } \\
\text { Retarded development } \\
\text { Retarded development }\end{array}$ & $\begin{array}{l}\text { Right inguinal hernia repair } \\
\text { Otitis media, congenital heart defect suspected } \\
\text { Absent right kidney (IVP) } \\
\text { Weight } 5700 \mathrm{~g} \\
\text { Weight } 12.5 \mathrm{~kg} \text {, height } 95 \mathrm{~cm} \text {, head circumference } 48.5 \mathrm{~cm} \text {, antimongoloid }\end{array}$ \\
\hline $\begin{array}{l}6 y \\
7 \frac{3}{4} y\end{array}$ & $\begin{array}{l}\text { Retarded development } \\
\text { Retarded development }\end{array}$ & $\begin{array}{l}\text { slant of eyelids, face appears old, fingers short, hands thick and fleshy } \\
\text { Evaluation by us (see text) } \\
\text { Weight } 17 \mathrm{~kg} \text {, height } 115 \mathrm{~cm} \text {, head circumference } 51 \mathrm{~cm}, 52 \text { out of } 65 \text { points } \\
\text { on Vineland Social Maturity Scale }\end{array}$ \\
\hline $9 \frac{3}{4} y$ & Acute anuria, painful abdominal mass & Renal failure of undetermined origin; haematoma at laparotomy; retroperitoneal \\
\hline $9 \frac{10}{1} \frac{0}{2} \mathrm{y}$ & Vomiting, dystrophia, oliguria & $\begin{array}{l}\text { hbrosis suspected; grand mal seizures } \\
\text { Death at } 9 \frac{11}{1} \frac{1}{2} \text { years from renal and circulatory failure }\end{array}$ \\
\hline
\end{tabular}

Dermatoglyphic analysis showed the following pattern: Right hand: axial triradius in $\mathrm{t}^{\prime \prime}$, atd $67^{\circ}$, digital pattern (finger 1 to 5): ulnar loops on all digits. Left hand: axial triradius in $\mathrm{t}^{\prime \prime}$ position, atd angle $70^{\circ}$, digital pattern (finger 1 to 5): whorl-arch -ulnar loop-whorl-ulnar loop.

Pathological data. Data, made available through the courtesy of Professor J. Oehme of Braunschweig Children's Hospital, revealed a large and invasive tumour conglomerate in the retroperitoneal area. The diagnostic impression was that this was an undifferentiated metastasizing malignant tumour of the retroperitoneal area whose points of origin could not be determined macroscopically. The histological picture suggested that it originated from an undifferentiated nephroblastoma (Wilms tumour), with the somewhat unusual feature of an even and diffuse infiltration of the solitary left kidney. A neuroblastoma as well as a reticulosarcoma could be excluded.
The right kidney was absent and the right renal artery was extremely hypoplastic overlaid with an abortive renal artery ostium. A hydroureter was present on the right. The foramen ovale was anatomically open but functionally closed. The right testis was in the abdominal cavity, the left in the inguinal canal. There was internal and external hydrocephalus.

Family and genetic marker data. The pedigree is shown in Fig. 1. Reproductive and developmental history in this kindred was unremarkable and physical examination of the proband's two sibs as well as the parents and grandparents did not reveal any evidence of a developmental anomaly. Eighteen autosomal loci were tested as genetic markers without evidence of irregular inheritance. The full data are available on request from the authors. The activities of 14 red blood cell enzymes were normal.

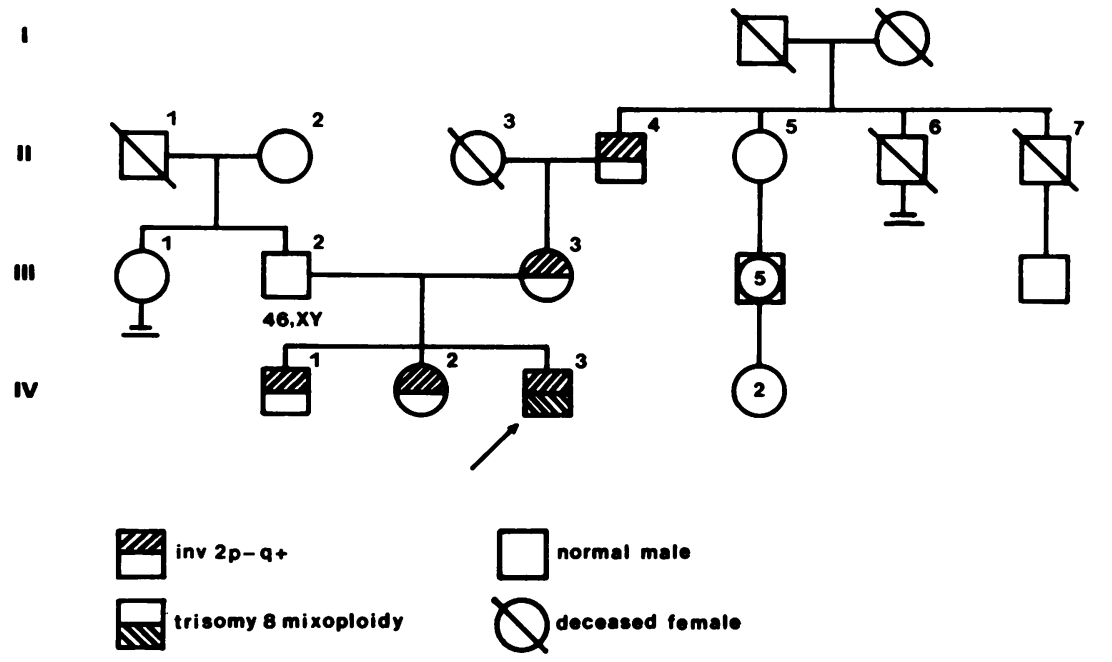

Fig. 1. Pedigree. 
Cytogenetics. The cytogenetic results are summarized in Table II. In both lymphocytes and fibroblasts one chromosome 2 was replaced by a submetacentric chromosome, with a reduced centromere index, in all metaphases of the propositus and 4 relatives (Figs. 2 and 3). This was interpreted as a pericentric inversion of chromosome 2 (inv $2 \mathrm{p}-\mathrm{q}+$ ). No loss of chromosomal material could be detected in standard as well as special stains. The banding pattern of the propositus and the other affected family members looked alike (Fig. 3). A detailed analysis of the $G$ banding pattern in 12 metaphases indicated that the break points were located in region 2 band 1 of the short $\operatorname{arm}(\mathrm{p} 21)$ and region 1 band 1 of the long arm (q11).

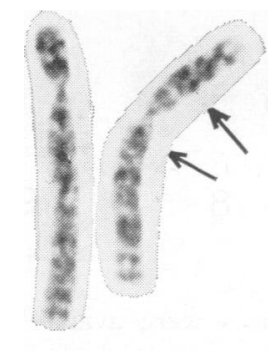

a b

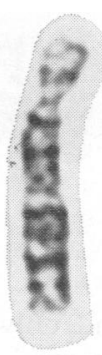

c

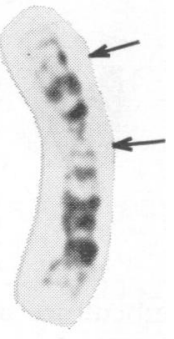

d

Fig. 2. Abnormal chromosome 2 of the propositus (a, c) and its normal homologue $(b, d)$, breakpoints indicated by arrows.

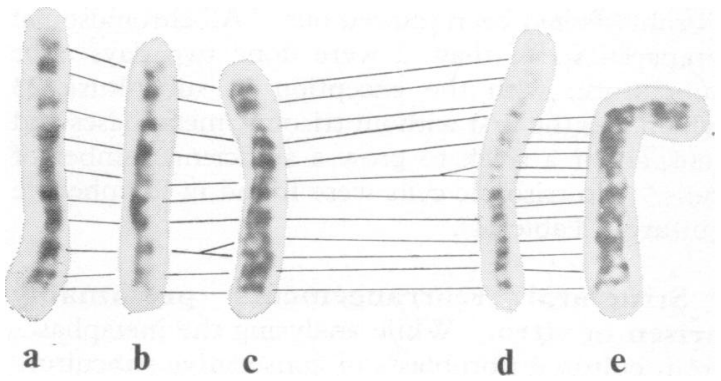

FIG. 3. Pericentric inversion of chromosome 2 in the propositus (c, e), his mother (b, d), and maternal grandfather (a). Positive G-bands connected by lines.

In 20 metaphases analysed, an additional Cgroup chromosome was present, which could be identified as chromosome 8 in 14 cells owing to a clear banding pattern of this group.

Analysis of the second series confirmed the presence of an additional chromosome 8 in chro-

TABLE II

SUMMARY OF CYTOGENETIC FINDINGS IN PROPOSITUS

\begin{tabular}{|c|c|c|c|c|c|c|}
\hline Tissue Examined & \multicolumn{3}{|c|}{${ }_{45}^{\text {No. of Chromosomes }}$} & \multicolumn{2}{|c|}{$\begin{array}{c}\text { Additional C Group } \\
\text { Chromosome } \\
\text { Present Identified } \\
\text { as } 8\end{array}$} & $\begin{array}{l}\text { Total No. of Metaphases } \\
\text { Examined }\end{array}$ \\
\hline $\begin{array}{l}\text { Lymphocytes } \\
1969 \text { (age 6) } \\
\text { 1972 (age 8) } \\
\text { Skin fibroblasts 1972 } \\
\text { Thaw 1: passage 11 } \\
\text { Thaw 2* : passage } 7(5) \dagger \\
8 \text { (7) } \\
10(14) \\
13(21) \\
14(24) \\
17(33) \\
22(47) \\
23(51) \\
24(60) \\
29(76) \\
30(78)\end{array}$ & $\begin{array}{l}3 \\
2\end{array}$ & $\begin{array}{r}98 \\
101 \\
3 \\
1 \\
1 \\
1 \\
1 \\
1 \\
1 \\
10 \\
10 \\
10 \\
10\end{array}$ & $\begin{array}{r}1 \\
16 \\
10 \\
9 \\
9 \\
9 \\
9 \\
9 \\
2\end{array}$ & $\begin{array}{r}0 \\
0 \\
20 \\
10 \\
9 \\
9 \\
9 \\
9 \\
9 \\
2 \\
0 \\
0 \\
0 \\
0\end{array}$ & $\begin{array}{r}14 \\
6 \\
9 \\
5 \\
7 \\
9 \\
9 \\
1\end{array}$ & $\begin{array}{r}101 \\
104 \\
20 \\
10 \\
10 \\
10 \\
10 \\
10 \\
10 \\
3 \\
10 \\
10 \\
10 \\
10\end{array}$ \\
\hline
\end{tabular}

* All cells with less than 46 chromosomes (result of technical loss) discarded.

$\uparrow$ Number of days from thawing to subculture. Chromosomal preparations of thaw 2 were done 2 days after subculture, except passage 23 when it was possible only after 7 days.

Pericentric inversion of chromosome 2 (inv(2)(p21q11)) present in all cells. 

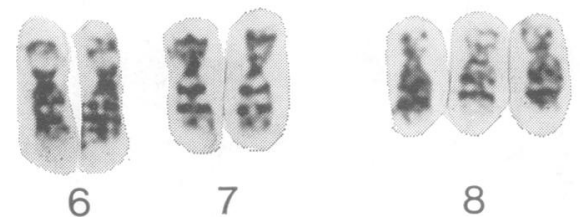

8

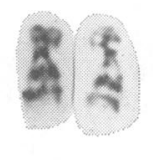

9

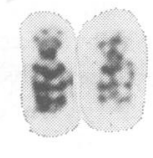

10

FIg. 4. Trisomy 8.

subculture and only 3 metaphases were available from chromosome preparations prepared from subculture 22 (47 days from thawing). Two of these 3 cells showed trisomy C (Table II). It appears, therefore, that the trisomic cells disappeared between the harvest of the 22nd and the 23rd subculture within 9 days, i.e. 51 days after the fibroblasts had been thawed out. All chromosomal preparations of thaw 2 were done two days after subculture, with the exception of subculture 23 which was the first without trisomic metaphases and took about a week to grow a sufficient number of cells. No trisomic cells were found in lymphocyte cultures (Table II).

Structural rearrangements presumably arisen in vitro. While analysing the metaphases from cultured fibroblasts of consecutive subculture (thaw 2, Table II), we found 9 different cells containing structurally abnormal chromosomes other than the pericentric inversion of chromosome 2, summarized in Table III. An additional screening of about $200 \mathrm{G}$-banded metaphases from passage 30 revealed 10 cells with structural alterations similar to those above $(t(13 p ; Y q)$ in $2 ; 3 q+$ in 8$)$.

\section{Discussion}

In this report the trisomic cells were restricted to cultured fibroblasts in their first 22 subculture generations, while none was found in lymphocytes. This restriction of trisomy 8 to cultured fibroblasts has not been recorded previously and raises obvious diagnostic difficulties. Furthermore, they disappeared rapidly from cultured fibroblasts and were absent after the 22nd subculture. One report (Neu, Bargman, and Gardner, 1969) has shown the disappearance of a cell line trisomic for a $\mathbf{C}$ group chromosome from blood in contrast to bone-marrow (fibroblasts not studied), while in another the proportion of trisomic cells increased in late fibroblast cultures (Chang, Niewczas-Late, and Uchida, 1969).

In other observations, trisomy 8 mixoploidy was present in both blood and skin, either without different distribution of the two cell lines or preponderance in blood (Bijlsma, Wijffels, and
Tegelaers, 1972; Caspersson et al, 1972; Crandall et al, 1974; Grouchy, Turleau, and Leonard, 1971; Jacobsen, Mikkelsen, and Rosleff, 1974; Laurent et al, 1971) or with a relatively higher proportion in fibroblasts (Atkins, Holmes, and Riccardi, 1974; Crandall et al, 1974; Schaumann, Červenka, and Gorlin, 1974; Walnavens et al, 1974). Our observations indicate that lymphocyte cultures may fail to indicate the state of mixoploidy, contrary to evidence in trisomy 21 (Taysi, Kohn, and Mellman, 1970). Non-disjunction occurring in vitro (Martin, Sprague, and Bryant, 1967) could not be formally excluded.

Presumably the familial pericentric inversion of chromosome 2 seen in our case is unrelated to the

TABLE III

TYPES OF CHROMOSOMAL STRUCTURAL REARRANGEMENTS PRESUMABLY ARISEN IN CULTURE (THAW 2 OF TABLE III)

\begin{tabular}{|c|c|c|c|}
\hline $\begin{array}{l}\text { Cell } \\
\text { No. }\end{array}$ & Passage No. & Type of Alteration & Remarks \\
\hline $\begin{array}{l}1 \\
2 \\
3 \\
4 \\
5 \\
6\end{array}$ & $\begin{array}{l}13 \\
14 \\
14 \\
23 \\
23 \\
24\end{array}$ & $\begin{array}{l}\text { Abnormal chromosome } 5 \\
14 q+ \\
16 q+ \\
3 q+ \\
\text { ?dic }(3 p+) \\
3 q+\text { chromatid break in } \\
\text { other } 3 p ;+ \text { ace }\end{array}$ & $\begin{array}{l}\text { Inversion? } \\
\text { Trisomy } 8 \\
\text { Fig. } 5 \mathrm{~b} \\
\text { Fig. } 5 \mathrm{a} \text {, cell } \\
\text { with } 60\end{array}$ \\
\hline $\begin{array}{l}7 \\
8 \\
9\end{array}$ & $\begin{array}{l}30 \\
30 \\
30\end{array}$ & $\begin{array}{l}3 q+; t(13 p ; 22 q) \\
t(13 p ; Y q) \\
t(13 p ; 22 q) ; 13 q+\end{array}$ & $\begin{array}{l}\text { chromosomes } \\
\text { Fig. } 5 c \text { and } 6 b \\
\text { Fig. } 6 a\end{array}$ \\
\hline
\end{tabular}

Trisomy 8 was only present in cell 3 (see Table II). Designation according to the Paris Conference 1971: + ace $=$ additional acentric fragment present; $14 \mathrm{q}+=$ elongation of the long arm $(q)$ of chromosome 14 ; ?dic $(3 p+)=$ presumably dicentric chromosome 3 with mosome $14 ;$ ?dic $(3 p+)=$ presumably dicentric chromosome 3 with
short $\operatorname{arm}(p)$ extended; $t(13 p ; 22 q)=$ translocation between the short short arm (p) extended; $t(13 p ; 22 q)=$ translocation between the
arm of chromosome 13 and the long arm of chromosome 22 .
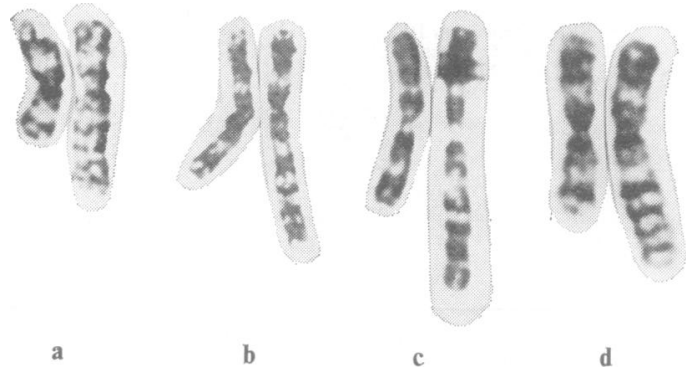

FIG. 5. Abnormal chromosomes 3 (see Table III). 
a

i

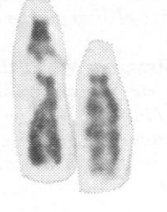

b
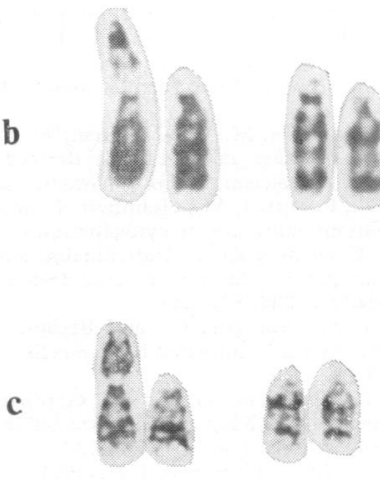

13
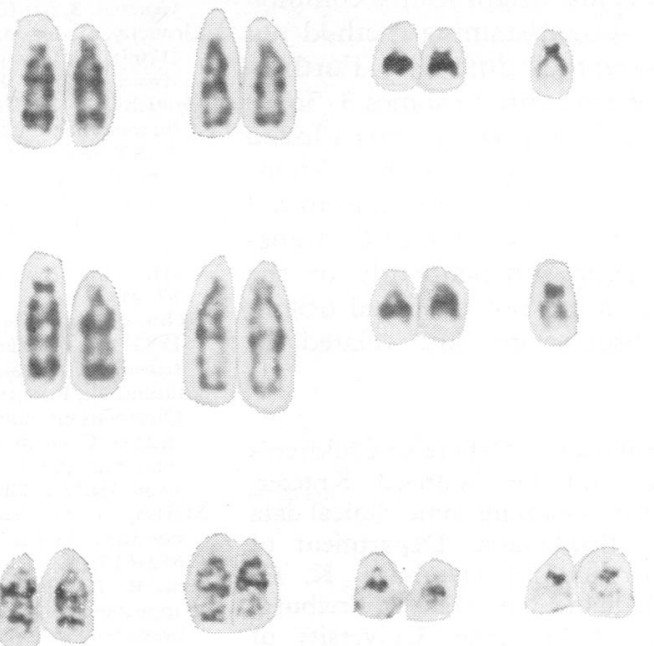

21
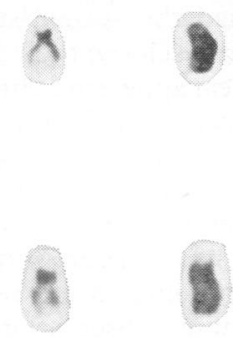

$22 \quad \mathrm{Y}$

Fig. 6. Spontaneous translocations apparently arisen in culture in 3 different (ells (a and $b: t(13 p ; 22 q), c: t(13 p ; Y q)$ ).

clinical problem and cannot be related to the phenotype. In other instances, pericentric inversion of chromosome 2 has been observed as a coincidental finding in phenotypically normal individuals (Jacobs et al, 1974; Weitkamp et al, 1969). Crossing over within the inverted segment, however, may lead to chromosomal imbalance, as has been observed in pericentric inversion of chromosome 13 (Parrington and Edwards, 1971; Taysi et al, 1973) (and our own unpublished observations). This apparently has not happened in the family described here, but should be expected in offspring of carriers of the inversion. Earlier, the concept of aneusomy by recombination has been invoked to explain phenotypic abnormalities in carriers of a cytologically inconspicuous inversion (Grouchy et al, 1966). The unspecific nature of the phenotypic finding in some of the observations (Grouchy et al, 1966; Therkelsen et al, 1973) makes one reluctant to accept here a concise karyotypephenotype correlation. Our observation shows that it is possible to miss the actual anomaly if the important chromosomal aberration occurs as mosaic in only one of the tissues examined and if it is under selective pressure from the normal cells. The discovery of trisomic cells in our patient was a coincidental finding when re-examining fibroblasts in search for detectable chromosomal deficiencies or duplications in the pericentric inversion of chro- mosome 2 present in our patient. Up to this time we had considered the possibility that the abnormal phenotype in our patient could have been the result of aneusomy by recombination (Grouchy et al, 1966). Our study shows how precarious this interpretation would have been.

The observation of structural chromosomal rearrangements including translocations, presumably arisen in culture, deserves mention though it cannot yet be interpreted in a meaningful manner.

Spontaneous translocations occurring in cultured skin fibroblasts have not been reported often (Ellis, 1963; Ford, 1964; Kohn, Aronson, and Mellman, 1974). Kohn et al (1974) related their finding to an infection with mycoplasma in culture. Mycoplasma infection has not been ruled out in our fibroblasts, but the rather ubiquitous event of mycoplasma infection and the presumably rare occurrence of spontaneous chromosomal rearrangements in cultured cells suggest that other mechanisms could be responsible. Structural chromosomal alterations of clonal origin have been described in cultured fibroblasts from patients with xeroderma pigmentosum (German, 1972), porokeratosis of Mibelli (Taylor, Harnden, and Fairburn, 1973), and in normal fibroblast cultures (A. M. R. Taylor, 1974, personal communication). We saw cells with seemingly identical structural anomalies as shown in Table III. The three trans- 
locations involving chromosome 13 (Fig. 6) could have been viewed as of clonal origin from a common ancestral cell, had the special staining method not been applied and disclosed their difference. Furthermore, the identical appearing chromosomes $3(3 q+)$ were observed in cells with and without the $13 p 22 q$ translocation, and one of the $13 p 22 q$ translocations was seen in a cell with two normal chromosomes 3 (cell 9). Therefore, either the two $D / G$ translocations must have arisen independently or the abnormal chromosomes 3 are not of clonal origin. Possibly all these observations are related to senescence of the cells.

We are indebted to Professor J. Oehme of Children's Hospital, Braunschweig, and Dr Wilfried Kratzer, Heidelberg, for assistance in obtaining some clinical data and specimens, Drs B. Brinkmann, Department of Forensic Medicine, University of Hamburg, K. G. Blume, Department of Medicine, University of Freiburg, C. Benöhr, Department of Medicine, University of Tübingen, for determination of the genetic marker, Mrs Hannah Schröder-Borm and Wulf Wöhler for technical assistance with the fibroblast cultures, and Drs Hugo W. Rüdiger and Thea Koske-Westphal for helpful suggestions.

\section{REFERENCES}

Atkins, L., Holmes, L. B., and Riccardi, V. M. (1974). Trisomy 8 Fournal of Pediatrics, 84, 302-304.

Bijlsma, J. B., Wijffels, J. C. H. M., and Tegelaers, W. H. H. (1972). C8 trisomy mosaicism syndrome. Helvetica Paediatrica Acta, 27, 281-298.

Böhmer, H. v., Wöhler, W., Wendel, U., Passarge, E., and Rüdiger, H. W. (1973). Studies on the optimal cooling rate for freezing human diploid fibroblasts. Experimental Cell Research, 79, 496498.

Caspersson, T., Lindsten, J., Zech, L., Buckton, K. E., and Price, W. H. (1972). Four patients with trisomy 8 identified by the fluorescence and Giemsa banding techniques. Fournal of Medical Genetics, 9, 1-7.

Chang, T. D., Niewczas-Late, V., and Uchida, I. A. (1969). Selection for trisomic cells in a mosaic fibroblast culture. Cytogenetics, 8, 410-414.

Crandall, B. F., Bass, H. N., Marcy, S. M., Glovsky, M., and Fish, C. H. (1974). The trisomy 8 syndrome: two additional mosaic cases. Fournal of Medical Genetics, 11, 393-398.

Ellis, J. R. (1963). Spontaneous translocation in a cell culture. Annals of Human Genetics, 26, 287-288.

Ford, C. E. (1964).Selection pressure in mammalian cell populations. In Cytogenetics of Cells in Culture, pp. 27-45. Ed. by R. J. C. Harris. Academic Press, New Ycrk.
German, J. (1972). Genes which increase chromosomal instability in somatic cells and predispose to cancer. Progress in Medical Genetics, 8, 61-101.

Grouchy, J. de, Aussannaire, M., Brissaud, H. E., and Lamy, M. (1966). Aneusomie de recombinaison: three further examples. American Fournal of Human Genetics, 18, 467-484.

Grouchy, J. de, Turleau, C., and Leonard, C. (1971). Etude en fluorescence d'une trisomie $C$ mosaique, probablement 8:46,XY 47,XY, ?8 +. Annales de Génétique, 14, 69-72.

Jacobs, P. A., Buckton, K. E., Cunningham, C., and Newton, M. (1974). An analysis of the break points of structural rearrangements in man. Fournal of Medical Genetics, 11, 50-63.

Jacobsen, P., Mikkelsen, M., and Rosleff, F. (1974). The trisomy 8 syndrome: report of two further cases. Annales de Génétique, 17, 87-94.

Kohn, G., Aronson, M., and Mellman, W. J. (1974). Spontaneous $D / G$ translocation in fibroblasts derived from a patient with trisomy 21 mosaicism. Clinical Genetics, 5, 113-115.

Laurent, C., Robert, J. M., Grambert, J., and Dutrillaux, B. (1971). Observations cliniques et cytogénétiques de deux adultes trisomiques $\mathrm{C}$ en mosaique. Individualisation du chromosome surnumeraire par la technique moderne de denaturation: $47, \mathrm{XY}, ? 8+$. Lyon Médical, 226, 827-833.

Martin, G. M., Sprague, C., and Bryant, J. S. (1967). Mitotic nondisjunction in cultivated human cells. Nature (London), 214, $612-613$.

Neu, R. L., Bargman, G. J., and Gardner, L. I. (1969). Disappearance of a 47,XX,C + leukocyte cell line in an infant who had previously exhibited 46,XX/47,XX,C + . Pediatrics, 43, 623-626.

Parrington, J. M. and Edwards, J. H. (1971). Patau's syndrome with $D_{1}$ duplication-deficiency derived from a maternal $D$ group pericentric inversion. Annals of Human Genetics, 35, 35-45.

Schaumann, B., Cervenka, J., and Gorlin, R. J. (1974). Dermatoglyphics in trisomy 8 mosaicism. Humangenetik, 24, 201-205.

Schneider, E. L. and Epstein, C. J. (1972). Replication rate and lifespan of cultured fibroblasts in Down's syndrome. Proceedings of the Society for Experimental Biology and Medicine, 141, 10921094.

Seabright, M. (1972). The use of proteolytic enzymes for the mapping of structural rearrangements in the chromosomes of man. Chromosoma, 36, 204-210.

Taylor, A. M. R., Harnden, D. G., and Fairburn, E. A. (1973). Chromosomal instability associated with susceptibility to malignant disease in patients with porokeratosis of Mibelli. Fournal of the National Cancer Institute, 51, 371-376.

Taysi, K., Bobrow, M., Balci, S., Madan, K., Atasu, M., and Say, B. (1973). Duplication/deficiency product of a pericentric inversion in man: a cause of $\mathrm{D}_{1}$ trisomy syndrome. Fournal of Pediatrics, 82, 263-268.

Taysi, K., Kohn, G., and Mellman, W. J. (1970). Mosaic mongolism. II. Cytogenetic studies. Fournal of Pediatrics, 76, 880-885.

Therkelsen, A. J., Hultén, M., Jonasson, J., Lindsten, J., Christensen, N. C., and Iversen, T. (1973). Presumptive direct insertion within chromosome 2 in man. Annals of Human Genetics, 36, 367-373.

Walravens, P. A., Grensher, A., Sparks, J. W., and Wesenberg, R. L. (1974). Trisomy 8 mosaicism. American fournal of Diseases of Children, 128, 564-566.

Weitkamp, L. R., Janzen, M. K., Guttormsen, S. A., and Gershowitz, H. (1969). Inherited pericentric inversion of chromosome number two: a linkage study. Annals of Human Genetics 33, 53-59. 